Evaluasi: Jurnal manajemen Pendidikan Islam

ISSN (P): 2580-3387, ISSN (E): 2615-2886

DOI : http://doi.org/10.32478/evaluasi.v5i2.629

Article Type : Original Research Article

\title{
MANAJEMEN PONDOK PESANTREN DALAM MENGEMBANGKAN KEWIRAUSAHAAN BERBASIS AGROBISNIS DI PONDOK PESANTREN DARUL AUFA
}

\author{
Hermon Susanto \\ Universitas Islam Negeri Sulthan Thaha Syaifuddin, Jambi Indonesia
}

Corresponding author: Hermonsusanto87@gmail.com

Submission Track:

Submission : :31-01-2021

Accept Submission: 24-05-2021

Avaliable Online : 11-09-2021

Copyright @ 2021 Author

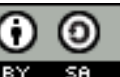

This work is licensed under a Creative Commons Attribution-ShareAlike 4.0

\begin{abstract}
Islamic boarding schools have modernized their education systems, where Islamic boarding schools have included general education systems such as Madrasahs or organized types of public schools such as junior high schools, high schools and even universities in their environment, not only that pesantren now also include entrepreneurship education.

In this study the authors used a case study research with a qualitative descriptive approach. Data collected through observation, interview and documentation techniques, then analyzed through data collection, data reduction, data display and conclusion drawing or verification. To ensure the validity of the data, the authors tested the validity of the data using technical triangulation, source triangulation and method triangulation.

The results of this study are management carried out by the head of the Buluh River Darul Aufa Islamic Boarding School in Muara Bulian District, Batanghari Regency in developing agrobinsist entrepreneurship, namely by implementing management functions, but the implementation of management functions has not been maximized, such as planning that has not been systematically organized. not yet on target, mobilization that has not been maximized and supervision that has not been programmed and is ongoing.
\end{abstract}


Keywords : Management of Islamic Boarding Schools; Agribusiness Entrepreneurship

\begin{abstract}
Abstrak
Pondok Pesantren telah memodernisasikan sistem pendidikannya, dimana dalam Pondok Pesantren telah dimasukkan sistem pendidikan umum seperti Madrasah atau menyelenggarakan tipe-tipe sekolah umum seperti SMP, SMA dan bahkan Perguruan Tinggi dalam lingkungannya, tidak hanya itu saja dewasa ini pesantren juga memasukkan pendidikan kewirausahaan.

Dalam penelitian ini penulis menggunakan penelitian studi kasus dengan pendekatan deskriptif kualitatif. Data yang dikumpulkan melalui teknik observasi, wawancara dan dokumentasi, kemudian dianalisis melalui Pengumpulan Data (Data Collection), Reduksi Data (Data Reduction), Penyajian Data (Data Display) dan Penarikan Kesimpulan atau Verification. Untuk menjamin keabsahan data, maka penulis menguji keabsahan data dengan menggunakan triangulasi teknik, triangulasi sumber dan triangulasi metode.

Hasil dari penelitian ini yaitu manajemen yang dilakukan pimpinan Pondok Pesantren Darul Aufa di Desa Sungai Buluh Kecamatan Muara Bulian Kabupaten Batanghari dalam mengembangkan kewirausahaan agrobinsis yaitu dengan menerapkan fungsi-fungsi manajemen, namun penerapan fungsi manajemen tersebut belum maksimal, seperti perencanaan yang belum dilakukan secara sistematis, pengorganisasian yang belum tepat sasaran, penggerakan yang belum maksimal dan pengawasan yang belum dilakukan secara terprogram dan berkelanjutan.
\end{abstract}

Kata Kunci: Manajemen Pondok Pesantren; Kewirausahaan Agrobisnis

\title{
A. PENDAHULUAN.
}

Pesantren merupakan lembaga pendidikan tradisional Islam yang bertujuan untuk memahami, menghayati, dan mengamalkan ajaran Islam dengan menekankan pentingnya moral agama Islam sebagai pedoman hidup bermasyarakat sehari-hari (Ahmad Muthohar, 2007, hal. 11). Dilihat dari kurikulum dan metode pembelajaran, pesantren dibedakan menjadi dua, yaitu: pertama; pesantren tradisional, adalah lembaga pesantren yang mempertahankan pelajaran kitab-kitab Islam klasik sebagai inti pendidikan. Adapun ciri-ciri pesantren tradisional di antaranya: (1) Kyai sebagai pimpinan pesantren, (2) Santri bermukim di asrama dan belajar pada kyai, (3) Asrama sebagai tempat tinggal para santri, (4) Pengajian sebagai bentuk pengajaran, dan (5) Masjid sebagai pusat kegiatan pondok pesantren. Kedua; pesantren modern, adalah pesantren yang melakukan pembaharuan (modernisasi) dalam sistem pendidikan, kelembagaan, pemikiran dan fungsi (Anik Farida, dkk, 2007, hal. 9). Ciri khas pondok pesantren modern (Anik Farida, dkk, 2007, hal. 23) di antaranya: (1) penekanan pada bahasa Arab percakapan, (2) memakai buku-buku literatur bahasa Arab kontemporer, (3) memiliki sekolah formal di bawah 
kurikulum Diknas (Departemen Nasional) atau Kemenag (Kementrian Agama), dan (4) tidak lagi memakai sistem pengajian tradisional.

Perubahan dan perkembangan kehidupan manusia lebih berkembang pesat ketika ia mengenal dan bersentuhan langsung dengan ilmu pengetahuan dan teknologi (IPTEK). IPTEK dapat memberikan manfaat dan kemudahan yang luar biasa bagi kehidupan. Produk iptek yang berdampak kepada masyarakat dewasa ini berkembang sangat cepat menuju masyarakat terbuka, masyarakat informasi global. Dalam kondisi demikian perubahan terjadi dengan cepat, mobilitas manusia dan barang sangat tinggi, komunikasi cepat, lancar dan akurat. Perubahan hampir terjadi dalam semua aspek kehidupan, pendidikan, sosial, budaya, ekonomi, politik, ideologi, nilai-nilai estetika.

Dewasa ini Pondok Pesantren telah memodernisasikan sistem pendidikannya, dimana dalam Pondok Pesantren telah dimasukkan sistem pendidikan umum seperti Madrasah atau menyelenggarakan tipe-tipe sekolah umum seperti SMP, SMA dan bahkan Perguruan Tinggi dalam lingkungannya, tidak hanya itu saja dewasa ini pesantren juga memasukkan pendidikan kewirausahaan. Sejalan dengan penyelenggaraan pendidikan formal di dalamnya, beberapa Pondok Pesantren modern menggalami pengembanggan pada aspek manajemen, organisasi, dan administrasi penggelolan keuanggan.

Di benak masyarakat umum, bayangan tentang santri yang belajar di pondok pesantren yaitu belajar dan berkutat dengan ilmu agama. Dari pagi hingga malam yang dilakukan selalu mengkaji Al Quran dan hadist. Itulah bayangan santri zaman 'old'. Zaman sudah berubah. Era gadget dan kaumnya millennial sedang bersinar. Modernitas menjadi tolok ukur perubahan. Tertinggal atau terus berubah mengikuti zaman. Tanpa pilih kasih, corak pemikiran modern ikut mengubah para pemimpin agama yaitu para kyai pondok pesantren. Era kompetisi dan kehidupan modern menuntut inovasi dan terobosan.

Belajar dari pola pikir beberapa Pondok Pesantren yang mengembangkan sistem wirausaha tersebut, pimpinan Pondok Pesantren Darul Aufa Sungai Buluh Kecamatan Muara Bulian Kabupaten Batanghari mencoba memberikan corak dan warna baru dalam sistem Pondok Pesantennya yaitu dengan mencoba mengembangkan sistem kewirausahaan agrobisnis dalam sistem Pondok Pesantren. Dengan mengembangkan agrobisnis pertanian, setidaknya akan memberi dampak dan manfaat yang besar bagi masyarakat sekitar sebagai pembelajaran. Juga menjadi tumpuan pendanaan santri dan pondok pesantren menuju kehidupan mandiri. Pilihan agrobisnis bidang pertanian dijadikan faktor penolong untuk membantu membiayai pesantren menjadi mandiri dalam pembiayaan pondok pesantren.

Dengan demikian, setiap kegiatan kewirausahaan (orientasi ekonomi untuk menyumbang kemandirian pondok pesantren) memiliki resiko yang cukup tinggi. Maka, pondok pesantren harus jeli dalam sistem manajerial agar tetap mampu menjaga sustainsibilitasnya. Menurut Nunun Supardi, dalam upaya menjaga keberlangsungan operasional manajemen pondok pesantren, kyai biasanya melaksanakan tiga hal; pertama, melibatkan partisipasi aktif masyarakat secara 
penuh. Kedua, pengembangan Sumber Daya Alam (SDA) yang dimiliki oleh kyai atau pesantren sendiri. Ketiga, manajamen kewirausahaan di pondok pesantren harus disokong oleh SDM yang memadai. Oleh karenanya, tak heran jika ada santri yang mengaji sambil mengelola sawah, tanah, dan kolam ikan. Noor Ahmady menyebutkan bahwa salah satu keberhasilan pondok pesantren menjalankan usaha adalah karena didukung oleh Sumber Daya Manusia yang tangguh (Noor Ahmady, 2009).

Pondok Pesantren Darul Aufa Sungai Buluh Kecamatan Muara Bulian Kabupaten Batanghari adalah salah satu Pondok Pesantren yang mengembangkan kewirausahaan agrobisnis dalam sistem pondok pesantren di wilayah provinsi jambi, kewirausahaan agrobisnis yang di kembangkan dalam Pondok Pesantren Darul Aufa Sungai Buluh Kecamatan Muara Bulian Kabupaten Batanghari sejak tahun 2008 yang di bina langsung oleh Departemen Pertanian Pusat RI, sampai dengan saat ini kewirausahaan agrobisnis masih berjalan. Kewirausahaan yang di kembangkan dalam sistem Pondok Pesantren Darul Aufa Sungai Buluh Kecamatan Muara Bulian Kabupaten Batanghari antara lain sebagai berikut :

1. Perkebunan kelapa sawit seluas 10;

2. Perkebunan karet seluas $10 \mathrm{Ha}$;

3. Peternakan sapi (penggemukan dan reproduksi);

4. Perikanan air tawar (ikan nila dan patin);

5. Budi daya sayur-sayuran.

Kewirausahaan agrobisnis tersebut diatas di kembangkan dalam lingkungan pesantren dan ada juga di luar lingkungan Pesantren. Keberhasilan Pondok Pesantren Darul Aufa Sungai Buluh Kecamatan Muara Bulian Kabupaten Batanghari dalam mengembangkan kewirausahaan agrobisnis saat ini tidak berkembang seperti sebelumnya, kewirausahaan yang di kembangkan oleh Pondok Pesantren Darul Aufa Sungai Buluh Kecamatan Muara Bulian Kabupaten Batanghari semakin hari semakin menurun produktivitasnya.

Berdasarkan hasil observasi penulis pada Pondok Pesantren Darul Aufa Sungai Buluh Kecamatan Muara Bulian Kabupaten Batanghari di mana penulis menemukan bahwa produktivitas kewirausahaan yang di kembangkan pada Pondok Pesantren Darul Aufa Sungai Buluh Kecamatan Muara Bulian Kabupaten Batanghari jambi saat ini mengalami fase penurunan, hal ini di sebabkan oleh kurang baiknya manejemen yang dilakukan dalam mengembangkan kewirausahaan agrobisnis tersebut. Pertama, perencanaan yang dilakukan oleh pimpinan Pondok Pesantren Darul Aufa Sungai Buluh Kecamatan Muara Bulian Kabupaten Batanghari dalam mengembangakan kewirausahaan agrobisnis dalam sistem pondok pesantren tidak terstruktur dengan baik, seperti tidak dilakukan perencanaan pemasaran hasil kewirausahaan agrobisnis. Kedua, pengorganisasian yang dilakukan dalam mengelola kewirausahaan agrobisnis pada Pondok Pesantren Darul Aufa Sungai Buluh Kecamatan Muara Bulian Kabupaten Batanghari tidak di serahkan kepada Sumber Daya Manusia yang ahli dalam bidang kewirausahaan agrobisnis, sehingga pimpinan pondok pesantren menggerakkan para santri santri yang di koordinir oleh ustadz maupun ustadzah. Ketiga, pimpinan Pondok Pesantren Darul Aufa Sungai Buluh 
Kecamatan Muara Bulian Kabupaten Batanghari tidak fokus lagi mengawasi perkembangan kewirausahaan agrobisnis yang di kembangkan dalam sistem Pondok Pesantren, hal ini di sebabkan oleh kesibukan dari pimpinan pondok pesantren, baik kegiatan yang ada dalam pondok pesantren maupun kegiatan di luar pondok pesantren.

Banyak lahan pertanian yang kosong tidak lagi dimanfaatkan oleh Pondok Pesantren Darul Aufa Sungai Buluh Kecamatan Muara Bulian Kabupaten Batanghari hal ini di karenakan permasalahan sebagaimana yang penulis uraikan pada Grand Tour di atas, jika pimpinan memiliki manajemen yang baik dalam mengembangkan kewirausahaan agrobisnis pada Pondok Pesantren Darul Aufa Sungai Buluh Kecamatan Muara Bulian Kabupaten Batanghari ini tentu akan sangat membantu keuangan dan kemajuan Pondok Pesantren Darul Aufa Sungai Buluh Kecamatan Muara Bulian Kabupaten Batanghari.

Kemudian berdasarkan rumusan masalah diatas, maka secara garis besar tujuan yang ingin dicapai dalam penelitian ini adalah ingin mengetahui secara umum tentang sistem manajemen kewirausahaan yang dibangun di pondok pesantren melalui hasil-hasil pertanian (agraria), adapun yang lebih khusus tujuan dari penelitian ini adalah sebagai berikut:

1. Ingin mengetahui Manajemen Agrobisnis di Pondok Pesantren Darul Aufa Sungai Buluh Kecamatan Muara Bulian.

2. Ingin mengetahui kendala Pondok Pesantren dalam Mengembangkan Kewirausahaan Berbasis Agrobisnis di Pondok Pesantren Darul Aufa Sungai Buluh Kecamatan Muara Bulian.

3. Ingin mengetahui Upaya yang dilakukan Pondok Pesantren dalam Mengembangkan Kewirausahaan Berbasis Agrobisnis di Pondok Pesantren Darul Aufa Sungai Buluh Kecamatan Muara Bulian.

Ada dua kemanfaatan dari pelaksanaan penelitian ini, yakni kegunaan secara teoritis dan kegunaan secara praktis. Secara teoritis bahwa hasil penelitian ini diharapkan dapat memberikan kontribusi pada upaya pengembangan wawasan khazanah pengembangan lembaga-lembaga. Sedangkan secara praktis, hasil penelitian ini diharapkan memberikan kontribusi pada berbagai institusi atau kalangan sebagai berikut:

1. Pondok Pesantren Darul Aufa Sungai Buluh Kecamatan Muara Bulian; hasil penelitian ini sebagai sumbangan pemikiran sekaligus sebagai bahan evaluasi juga masukan dalam peningkatan pengembangan wirausaha lembaga.

2. Masyarakat umum; hasil penelitian ini dapat menjadi pertimbangan bagi upayaupaya pengelolaan dan strategi pengembangan wirausaha pesantren serta merealisasikannya di dunia lembaga.

3. UIN Sulthan Thaha Syafudiin Jambi; hasil penelitian ini dapat menjadi salah satu literatur bagi keluarga besar UIN Sulthan Thaha Syafudiin Jambi baik sebagai bahan bacaan untuk memperluas wawasan dan pengelolaan lembaga maupun sebagai bahan pustaka bagi penyusunan tesis atau makalah.

4. Peneliti; pada dasarnya penelitian ini dilakukan sebagai salah satu syarat untuk 
memperoleh gelar Sarjana Strata 2 (dua) di UIN Sulthan Thaha Syafudiin Jambi. Selain itu hasil penelitian ini tentu dapat memberikan informasi baru yang dapat memperluas wawasan dan cakrawala pemikiran peneliti mengenai lembaga serta melatih diri dalam research ilmiah.

Peneliti menyadari bahwa secara substansial penelitian ini tidaklah sama sekali baru. Dalam kajian pustaka ini, peneliti akan mendeskripsikan beberapa karya yang relevansinya dengan judul dan untuk menjaga keabsahan materi dan subjek penelitian serta untuk membahas temuan penelitian, maka peneliti telah melakukan identifikasi sumber -sumber dalam bentuk hasil-hasil temuan penelitian yang telah ada dan mempunyai relevansi dengan penelitian yang akan dilakukan, dengan alasan agar tidak terjadi pengulangan pada lokasi penelitian dari subjek yang sama, dan juga dapat membantu mengembangkan analisis dan pemahaman terhadap temuan penelitian. Sebagian dari hasil penelitian Mahasiswa Pascasarjana UIN STS Jambi, menurutnpeneliti mempunyai relevansi dengan penelitian yang akan peneliti lakukan.

Hasil penelitian yang dianggap mempunyai relevansi itu adalah penelitian yang dilakukan saudara Muhammad Aman, yang berjudul Manajemen Wirausaha Pondok Karya Pembangunan Al-Hidayah Kota Jambi (Peran Usaha Bisnis dalam Meningkatkan Mutu Pembelajaran), yang mengemukakan bahwa usaha-usaha yang diadakan Pondok PKP al-Hidayah dimaksudkan untuk memberikan kontribusi pembiayaan manajemen pondok dalam meningkatkan mutu pemebelajaran telah berperan dengan baik untuk tujuan tersebut. Kontribusi telah dirasakan sebagai kebutuhan yang perlu dimaksimalkan sebagai sumber penunjang kemasukan lainnya (Muhammad Aman, 2015).

\section{B. METODE PENELITIAN}

Penelitian ini termasuk penelitian studi kasus yang dilakukan dengan cara mengamati orang-orang dalam kondisi yang wajar. Yaitu dengan pendekatan deskriprif kualitatif. Dalam penelitian deskriptif kualitatif data yang dikumpulkan bukan angka-angka tetapi berupa kata-kata atau gambar. Data yang dimaksud berasal dari naskah wawancara, catatan lapangan, foto, videotape, dokumen pribadi, dan catatan resmi lainnya.

Teknik pengumpulan data yang peneliti lakukan dengan cara, yaitu:

\section{Observasi}

Metode ini dimaksud dengan mengamati perbuatan, sikap dan tingkah laku informan. Dalam hal ini peneliti mengamati langsung Manajemen Pondok Pesantren dalam mengembangkan Kewirausahaan berbasis agrobisnis di Pondok Pesantren Darul Aufa Sungai Buluh Kecamatan Muara Bulian.

Observasi ini dilakukan untuk mendapatkan data tentang yang peneliti butuhkan melalui observasi peneliti langsung melakukan pengamatan umum tentang:

a. Aktivitas Pimpinan Pondok Pesantren Darul Aufa Sungai Buluh Kecamatan Muara Bulian 
b. Aktivitas Tenaga Pendidik Pondok Pesantren Darul Aufa Sungai Buluh Kecamatan Muara Bulian

\section{Wawancara}

Pengumpulan data melalui wawancara kualitatif menggunakan pendekatan terstruktur yang dilengkapi dengan pedoman wawancara (yaitu pertanyaan penelitian). Wawancara yang digunakan merupakan jenis wawancara yang terstruktur dimana pewawancara dalam hal ini peneliti menetapkan sendiri masalahnya dan menetapkan pertanyaan-pertanyaan yang diajukan, hal ini dilakukan dikarenakan peneliti ingin mengetahui secara langsung jawaban dari hipotesis yang ada.

\section{Dokumentasi}

Pengumpulan data melalui dokumentasi, diperlukan seperangkat alat atau instrument yang memandu untuk pengambilan data-data dokumen. Metode dokumentasi digunakan untuk mendapatkan informasi non manusia, sumber informasi (data) non manusia ini berupa catatan-catatan, pengumuman, instruksi, aturan-aturan, laporan, keputusan atau surat-suratnya, catatn-catatan dan arsip-arsip yang ada kaitannya dengan fokus penelitian. Data yang dikumpulkan mengenai teknik tersebut berupa kata-kata, tindakan dan dokumen tertulis lainnya, dicatat dengan menggunakan catatn-catatan.

Langkah-langkah yang ditempuh penulis dalam menganlisis data sebagai berikut:

\section{Pengumpulan Data (Data Collection)}

Dilaksanakan dengan cara pencarian data yang diperlukan terhadap berbagai jenis data dan bentuk data yang ada di lapangan, kemudian melaksanakan pencatatan data di lapangan.

2. Reduksi Data (Data Reduction)

Apabila data sudah terkumpul langkah selanjutnya adalah mereduksi data. Proses reduksi data dalam penelitian ini dapat peneliti uraikan sebagai berikut: pertama, peneliti merangkum hasil catatan lapangan selama proses penelitian berlangsung yang masih bersifat kasar atau acak ke dalam bentuk yang lebih mudah dipahami. Peneliti juga mendeskripsikan terlebihdahulu hasil dokumentasi berupa foto-foto dan dokumen lainnya. Setelah selesai, peneliti melakukan reflektif. Reflektif merupakan karangka berpikir dan pendapat atau kesimpulan dari peneliti sendiri.

3. Penyajian Data (Data Display)

Setelah data direduksi, maka langkah selanjutnya adalah mendisplaykan data. Melalui penyajian data tersebut, maka data terorganisasikan tersusun dalam pola hubungan, sehingga akan mudah dipahami. Penyajian data dalam penelitian ini peneliti paparkan dengan teks yang bersifat naratif.

4. Penarikan Kesimpulan atau Verification

Dari semua data yang telah diperoleh oleh peneliti di lapangan selanjutnya peneliti harus menganalisis hasil penelitiannya, banyak teknik yang digunakan salah satu diantaranya, data yang telah dikumpulkan itu kemudian dikelompokkan atau memfokuskan hasil yang didapat dengan penelitian, dari pengelompokkan data tersebut penelitian dapat menyajikannya, penyajian dapat melalui seminar yang 
kemudian akan ditarik suatu kesimpulan sebagai bukti bahwa penelitian telah selesai dilakukan.

\section{HASIL DAN PEMBAHASAN}

Menajemen yang dilakukan pimpinan Pondok Pesantren Darul Aufa Sungai Buluh Kecamatan Muara Bulian Kabupaten Batanghari dalam mengembangkan kewirausahaan agrobisnis yaitu:

a. Menyusun Perencanaan

Perencanaan ialah sejumlah kegiatan yang ditentukan sebelumnya untuk dilaksanakan pada suatu periode tertentu dalam rangka mencapai tujuan yang telah ditetapkan (Husaini Usman, 2010, hal. 65). Planning ialah menetapkan pekerjaan yang harus dilaksanakan oleh kelompok untuk mencapai tujuan yang digariskan (George R. Terry, 2009, hal. 17). Planning menentukan tujuan-tujuan yang hendak dicapai selama satu masa yang akan datang dan apa yang harus diperbuat agar dapat mencapai tujuan-tujuan itu (George R. Terry, dan Leslie W. Rue, 2011, hal 9).

Perencanaan dalam manajemen pondok pesantren Darul Aufa Kecamatan Sungai Buluh Kabupaten Batanghari merupakan tindakan penetapan yang ingin dicapai oleh pondok pesantren Darul Aufa Kecamatan Sungai Buluh Kabupaten Batanghari, kemudian personalia yang dibutuhkan untuk mengelola manejemen pondok pesantren Darul Aufa Kecamatan Sungai Buluh Kabupaten Batanghari, perencanaan harus dilakukan secara sistematis agar tercapai semua perencanaan yang telah ditetapkan dapat tercapai dengan maksimal.

Hasil observasi yang penulis lakukan tersebut senada dengan hasil wawancara penulis dengan pimpinan Pondok Pesantren Darul Aufa Kecamatan Sungai Buluh Kabupaten Batanghari yang memberikan penjelasan bahwa dalam mengembangkan kewirausahaan agrobisnis pada Pondok Pesantren Darul Aufa Kecamatan Sungai Buluh Kabupaten Batanghari yang sudah dilaksanakan mulai tahun 2008 ini memang tidak melakukan perencanaan secara sistematis dalam mengembangkan kewirausahaan agrobisnis, tidak ada perencanaan yang sfesifik dan tersusun secara sistematis dalam mengembangkan kewirausahaan agrobisnis pada Pondok Pesantren Darul Aufa Kecamatan Sungai Buluh Kabupaten Batanghari.

Pimpinan Pondok Pesantren Darul Aufa Kecamatan Sungai Buluh Kabupaten Batanghari menjelaskan bahwa perencanaan dalam melakukan setiap tindakan maupun setiap kegiatan sangat penting sekali, dan kami sangat menyadari bahwa penyebab tidak berkembangnya kewirausahan agrobisnis pada Pondok Pesantren Darul Aufa Kecamatan Sungai Buluh Kabupaten Batanghari yaitu tidak efektifnya perencanaan yang kami lakukan.

Seharusnya perencanaan ini harus disusun secara sistematis dengan merangkum seluruh saran dan pendapat dari semua anggota yang ada dalam sistem Pondok Pesantren Darul Aufa Sungai Buluh Kecamatan Muara Bulian Kabupaten 
Batanghari, sehingga pimpinan Pondok Pesantren Darul Aufa Sungai Buluh Kecamatan Muara Bulian Kabupaten Batanghari dapat menyusun perencanaan dengan menganalisis seluruh masukan dan saran dari para anggotanya sehingga perencanaan tersebut menjadi acuan untuk mengembangkan kewirausahaan agrobisnis yang dikembangkan dalam Pondok Pesantren Darul Aufa Sungai Buluh Kecamatan Muara Bulian Kabupaten Batanghari.

\section{b. Melakukan Pengorganisasian}

Pengorganisasian diartikan sebagai kegiatan pembagian tugas- tugas pada orang yang terlibat dalam kerjasama sekolah. Karena tugas ini demikian banyak dan tidak dapat diselesaikan satu orang saja, tugas-tugas ini dibagi untuk dikerjakan oleh masing-masing unit organisasi. kegiatan pengorganisasian menentukan siapa yang akan melaksanakan tugas sesuai prinsip pengorganisasian (Syaiful Sagala. 2008, hal 58).

Pengorganisasian yang dilakukan oleh Pimpinan Pondok Pesantren Darul Aufa Sungai Buluh Kecamatan Muara Bulian Kabupaten Batanghari untuk melaksanakan kewirausahaan agrobisnis yang dikembangkan dalam sistem Pondok Pesantren Darul Aufa Sungai Buluh Kecamatan Muara Bulian Kabupaten Batanghari menurut hemat penulis berdasarkan observasi belum tetap sasaran, hal ini dikarenakan kewirausahaan agrobisnis yang dikembangkan oleh Pondok Pesantren Darul Aufa Sungai Buluh Kecamatan Muara Bulian Kabupaten Batanghari mengalami fase kemunduran, karena pengorganisasian atau pemberian tugas yang dilakukan oleh Pimpinan Pondok Pesantren Darul Aufa Sungai Buluh Kecamatan Muara Bulian Kabupaten Batanghari tidak tetap sasaran. Pengorganisasian atau pemberian tugas untuk mengembangkan kewirausahaan agrobisnis ini yang dilakukan oleh Pimpinan Pondok Pesantren Darul Aufa Sungai Buluh Kecamatan Muara Bulian Kabupaten Batanghari kepada ustadz yang difungsikan pimpinan pondok pesantren yang tidak memiliki wawasan dan keilmuan dalam bidang kewirausahaan agrobisnis sehingga perkembangan kewirausahan agrobisnis ini tidak berkelanjutan.

Hasil observasi dan hasil wawancara penulis sebagaimana yang telah penulis uraikan diatas, maka dapat dipahami bahwa pimpinan Pondok Pesantren Darul Aufa Sungai Buluh Kecamatan Muara Bulian Kabupaten Batanghari dalam melakukan pengorganisasian dalam mengembangkan kewirausahaan agrobisnis pada Pondok Pesantren Darul Aufa Sungai Buluh Kecamatan Muara Bulian Kabupaten Batanghari tidak diserahkan kepada orang yang berkompetensi dan berkualifikasi dalam bidangnya, sehingga kewirausahaan agrobisnis yang dikembangkan oleh Pondok Pesantren Darul Aufa Sungai Buluh Kecamatan Muara Bulian Kabupaten Batanghari mengalami kemunduran produktifitas yang sangat signifikan. Padahal kewirausahaan agrobisnis yang dikembangkan oleh Pondok Pesantren Darul Aufa Sungai Buluh Kecamatan Muara Bulian Kabupaten Batanghari sejak tahun 2008 sampai dengan tahun 2014 berkembang dengan pesat dan menjadi rujukan Pondok Pesantren lainnya 
dalam hal pengembangan kewirausahaan agrobisnis dalam sistem pendidikan Pondok Pesantren, baik dalam wilayah Provinsi Jambi maupun diluar Provinsi.

c. Melakukan Penggerakan

Setelah perencanaan dan pengorganisasian selesai dilakukan, maka langkah selanjutnya yang perlu ditempuh dalam manajemen adalah mewujudkan rencana tersebut dengan mempergunakan organisasi yang terbentuk. Langkah tersebut adalah actuating yang secara harfiah diartikan sebagai memberi bimbingan namun istilah tersebut lebih condong diartikan penggerak atau pelaksanaan. Actuating, atau disebut juga "gerakan aksi" mencakup kegiatan yang dilakukan seorang manager untuk mengawali dan melanjutkan kegiatan yang ditetapkan oleh unsur perencanaan dan pengorganisasian agar tujuan-tujuan dapat tercapai (George R. Terry, 2009, hal. 17).

Penggerakan dalam mengembangkan kewirausahaan agrobisnis yang dilakukan oleh pimpinan Pondok Pesantren Darul Aufa Sungai Buluh Kecamatan Muara Bulian Kabupaten Batanghari yaitu dengan menggerakkan para ustadz beserta para santri Pondok Pesantren Darul Aufa Sungai Buluh Kecamatan Muara Bulian Kabupaten Batanghari, tidak tersedianya sumber daya manusia yang berkompeten dalam bidang kewirausahaan agrobisnis mengharuskan pimpinan Pondok Pesantren Darul Aufa Sungai Buluh Kecamatan Muara Bulian Kabupaten Batanghari untuk memberdayakan sumber daya yang ada, yaitu ustadz dan santri.

Berdasarkan hasil wawancara serta hasil observasi sebagaimana yang telah penulis uraikan diatas, maka dalam hal ini dapat dipahami bahwa penggerakan yang dilakukan oleh pimpinan Pondok Pesantren Darul Aufa Sungai Buluh Kecamatan Muara Bulian Kabupaten Batanghari dalam mengembangkan kewirausahaan agrobisnis yang dikembangkan dalam sistem Pondok Pesantren yaitu dengan menggerakkan para ustadz dan para santri untuk melaksanakan kewirausahaan agrobisnis tersebut. kewirausahaan agrobisnis yang dikembangkan oleh Pondok Pesantren Darul Aufa Sungai Buluh Kecamatan Muara Bulian Kabupaten Batanghari antara lain perkebunan kepala sawit dan karet, penggemukan dan reproduksi sapi, perternakan ikan nila dan patin serta pembudidayaan sayur-sayuran.

d. Melaksanakan pengawasan

Pangawasan dan evaluasi dapat diartikan sebagai salah satu kegiatan untuk mengetahui realisasi perilaku personel dalam organisasi pendidikan dan apakah tingkat pencapaian tujuan pendidikan sesuai dengan yang dikehendaki, kemudian apakah perlu diadakan perbaikan. Pengawasan dilakukan untuk mengumpulkan data tentang penyelenggaraan kerja sama antara guru, kepala madrasah, konselor, supervisor, dan petugas madrasah lainnya dalam institusi satuan pendidikan. Pada dasarnya ada tiga langkah yang perlu ditempuh dalam melaksanakan pengawasan, yaitu (1) menetapkan alat ukur atau standar, (2) mengadakan penilaian atau evaluasi, dan (3) mengadakan tindakan perbaikan atau koreksi dan tindak lanjut. Oleh sebab itu, kegiatan pengawasan itu dimaksudkan untuk mencegah penyimpangan dalam pelaksanaan pekerjaan, menilai proses dan hasil kegiatan dan sekaligus melakukan tindakan perbaikan (Ngalim Purwanto, 2009, hal. 107). 
Pengawasan yang dilakukan pimpinan Pondok Pesantren Darul Aufa Sungai Buluh Kecamatan Muara Bulian Kabupaten Batanghari belum maksimal. Wawancara dan observasi yang penulis lakukan sebagaimana yang telah penulis uraikan sebelumnya bahwa pelaksanaan pengawasan terhadap kegiatan kewirausahaan agrobisnis pada Pondok Pesantren Darul Aufa Sungai Buluh Kecamatan Muara Bulian Kabupaten Batanghari dilakukan oleh pimpinan Pondok, namun pelaksanaan pengawasan tersebut tidak dilakukan dengan maksimal, karena pimpinan pondok hanya terfokus mengawasi kewirausahaan agrobisnis di bidang pembudidayaan sayursayuran saja, dan pelaksanaan pengawasan tersebut juga tidak dilakukan secara berkelanjutan. Tentu kondisi seperti ini tidak harus terjadi, karena sebagai pimpinan pengawasan harus dilakukan oleh pimpinan dan pengawasan juga seharusnya dilaksanakan secara berkesinambungan.

Pengawasan merupakan fungsi terakhir dari manajemen yang harus dilaksanakan langsung oleh pimpinan, pengawasan dilaksankan bertujuan untuk memastikan apakah pelaksanaan sudah sesuai dengan perencanaan dan standar yang telah ditetapkan serta untuk mengetahui apa yang menjadi kendala dalam pelaksanaan tersebut sehingga pimpinan akan mencari solusi dalam mengatasi kendala tersebut. untuk mendapatkan hasil yang maksimal, pengawasan bukan hanya dilakukan sekedarnya saja, akan tetapi pengawasan harus dilakukan secara sistematis dan berkelanjutan.

Pengawasan terhadap pengembangan kewirausahaan agrobisnis pada Pondok Pesantren Darul Aufa Sungai Buluh Kecamatan Muara Bulian Kabupaten Batanghari dilakukan langsung oleh pimpinan Pondok Pesantren, sebagaimana pernyataan pimpinan Pondok Pesantren Darul Aufa Sungai Buluh Kecamatan Muara Bulian Kabupaten Batanghari melalui wawancara menjelaskan bahwa pelaksanaan pengawasan terhadap pelaksanaan pengembangan kewirausahaan agrobisnis pada Pondok Pesantren Darul Aufa Sungai Buluh Kecamatan Muara Bulian Kabupaten Batanghari ini saya langsung melakukannya, namun ada juga yang tidak langsung saya yang melakukan pengawasannya, dan jika saya tidak bisa melaksanakan pengawasan dikarenakan ada keperluan lain, maka saya menugaskan sekretaris Pondok Pesantren Darul Aufa Sungai Buluh Kecamatan Muara Bulian Kabupaten Batanghari untuk melaksanakannya dan atau ustadz yang lainnya.

Pengawasan adalah suatu tindakan untuk mengetahui sejauhmana pelaksanaan dilaksanakan, dan untuk mengetahui apakah pelaksanaan sesuai dengan rencana yang telah ditetapkan. Pengawasan yang dilakukan pimpinan Pondok Pesantren Darul Aufa Sungai Buluh Kecamatan Muara Bulian Kabupaten Batanghari belum maksimal. Wawancara dan observasi yang penulis lakukan sebagaimana yang telah penulis uraikan sebelumnya bahwa pelaksanaan pengawasan terhadap kegiatan kewirausahaan agrobisnis pada Pondok Pesantren Darul Aufa Sungai Buluh Kecamatan Muara Bulian Kabupaten Batanghari dilakukan oleh pimpinan Pondok, namun pelaksanaan pengawasan tersebut tidak dilakukan dengan maksimal, karena pimpinan pondok hanya terfokus mengawasi kewirausahaan agrobisnis di bidang pembudidayaan sayur-sayuran saja, dan pelaksanaan pengawasan tersebut juga tidak 
dilakukan secara berkelanjutan. Tentu kondisi seperti ini tidak harus terjadi, karena sebagai pimpinan pengawasan harus dilakukan oleh pimpinan dan pengawasan juga seharusnya dilaksanakan secara berkesinambungan.

Adapun kendala yang dihadapi pimpinan ondok Pesantren Darul Aufa Sungai Buluh Kecamatan Muara Bulian Kabupaten Batanghari dalam mengembangkan kewirausahaan agrobisnisnya yaitu sebagai berikut :

1. Sumber Daya Manusia

Sumber Daya Manusia merupakan hal yang sangat penting dalam setiap kegiatan yang meruapkan pelaku dalam kegiatan itu sendiri. Tentu dalam hal ini adalah sumber daya yang berkompetensi dalam bidangnya, karena kegiatan yang dilaksanakan oleh orang yang tidak ahli dalam bidangnya maka sudah bisa dipastikan pencapaian kegiatan tersebut tidak maksimal. Salah satu kendala yang dihadapi pimpinan Pondok Pesantren Darul Aufa Sungai Buluh Kecamatan Muara Bulian Kabupaten Batanghari dalam mengembangkan kegiatan kewirausahaan agrobisnisnya adalah tidak tersedianya Sumber Daya Manusia yang berkompetensi dalam bidang agrobisnis.

Pondok Pesantren Darul Aufa Sungai Buluh Kecamatan Muara Bulian Kabupaten Batanghari sampai dengan saat ini belum memiliki tenaga yang berkompetensi dalam bidang agrobisnis dan selama pimpinan Pondok Pesantren Darul Aufa Sungai Buluh Kecamatan Muara Bulian Kabupaten Batanghari hanya mengfungsikan para ustadz serta para satri. Pada awalnya kewirausahaan agrobisnis yang dikembangkan oleh pondokPesantren Darul Aufa Sungai Buluh Kecamatan Muara Bulian Kabupaten Batanghari ini sangat berkembang, namun beberapa tahun terakhir terjadi kemunduran dan beberapa kewirausahaan agrobisnis tidak berjalan lagi.

Pondok pesantren Darul Aufa Sungai Buluh Kecamatan Muara Bulian Kabupaten Batanghari merupakan pondok pesantren modern yang juga terkenal dengan sistem kewirausahaan agrobisnisnya. Namun pengelolaan kegiatan agrobisnis pada pondok pesantren Darul Aufa Sungai Buluh Kecamatan Muara Bulian Kabupaten Batanghari belum dikelola secara profesional. Pengelolaan kegiatan agrobisnis pada pondok pesantren harus dilakukan oleh orang-orang yang ahli dalam bidang agrobisnis, karena jika pengelolaan kegiatan agrobisnis tidak dilakukan oleh orangorang yang tidak berkompeten dalam bidang bidangnya, maka sudah bisa dipastikan pelaksanaan kegiatan agrobisnis pada pondok pesantren tidak efektif, efesien dan tidak akan terlaksana dengan maksimal.

2. Pemasaran Produk Agrobisnis

Dalam menjalankan sebuah usaha, peran dan strategi pemasaran sangatlah penting untuk mendukung kesuksesan usaha yang dijalankan, tak terkecuali dalam menekuni kewirausahaan agrobisnis. Pelaku kewirausahaan agrobisnis membutuhkan strategi agar pruduk kewirausahaan agrobisnisnya mampu untuk dipasarkan sesuai dengan tujuannya. Secara umum pemasaran hasil kewirausahaan agrobisnis tidak jauh berbeda dengan pemasaran produk lainnya, namun kenyataannya pelaku kewirauhsaan agrobisnis masih kesulitan untuk memasarkan hasil produknya. Atas 
dasar inilah perlunya strategi pemasaran yang baik bagi para pelaku kewirausahaan agrobisnis sehingga hasil kewirausahaan agrobisnisnya dapat di pasarkan secara maksimal.

Pimpinan Pondok pesantren Darul Aufa Sungai Buluh Kecamatan Muara Bulian Kabupaten Batanghari kembali menjelaskan bahwa selama ini pemasaran yang kami lakukan dari hasil usaha agrobisnis kami jual di pasar keramat tinggi muara bulian, terkadang konsumen juga langsung datang ke pondok kami, namun mereka hanya membeli sebagian kecil saja tidak seluruh hasil usaha kami di beli mereka. Selain dari pada itu usaha perikanan kami juga kesulitan untuk memasarkannya. Anang Mukri juga menjelaskan bahwa hasil usaha agrobisnis yang di kembangkan pada Pondok pesantren Darul Aufa Sungai Buluh Kecamatan Muara Bulian Kabupaten Batanghari terkendala dengan pemasarannya. Kami belum mampu memasarkan hasil usaha agrobisnis Pondok Pesantren dengan maksimal.

3. Perubahan Cuaca

Pondok Pesantren Darul Aufa Sungai Buluh Kecamatan Muara Bulian Kabupaten Batanghari mengembangkan kewirausahaan agrobisnis sejak tahun 2008, dalam perjalannya salah satu kendala dalam mengembangkan usaha tersebut adalah perubahan cuaca. Seperti yang telah di uraikan sebelumnya, kewirausahan yang dikembangkan oleh Pondok pesantren Darul Aufa Sungai Buluh Kecamatan Muara Bulian Kabupaten Batanghari antara lain perkebunan, perternakan, perikanan dan sayur-sayuran. Dari berbagai usaha yang dikembangkan oleh Pondok Pesantren Darul Aufa Sungai Buluh Kecamatan Muara Bulian Kabupaten Batanghari ini, yang terkendala oleh perubahan cuaca adalah usaha perikanan dan sayur-sayuran.

Pimpinan Pondok Pesantren Darul Aufa Sungai Buluh Kecamatan Muara Bulian Kabupaten Batanghari juga menjelaskan bahwa perubahan cuaca menjadi kendala dalam mengembangkan usaha-usaha agrobisnis kami, seperti perikan, jika musim penghujan kami tidak dapat berbuat banyak, karena kolam perikanan tersebut kena banjir dan ikan-ikan yang ada di dalam kolam tersebut keluar, begitu juga jika musim kemarau, maka kolam perikanan tersebut mengalami kekeringan sehingga tidak dapat dioperasikan. Begitu juga sebaliknya dengan usaha sayur-sayuran, jika musim kemarau sayur-sayuran tidak tumbuh dengan subur karena tidak disiram, hal ini disebabkan sumber air jauh dengan lahan sayur-sayuran tersebut.

Pernyataan dari pimpinan Pondok Pesantren Darul Aufa Sungai Buluh Kecamatan Muara Bulian Kabupaten Batanghari tersebut benar adanya, karena berdasarkan hasil observasi penulis lahan sayur-sayuran jauh dari sumber mata air dan kemudian kolam perikanan juga terletak di daratan rendah sehingga musim penghujan akan menyebabkan ikan-ikan yang ada dikolam keluar. Kondisi yang demikian tentu akan menjadi penghambat bagi Pondok Pesantren Darul Aufa Sungai Buluh Kecamatan Muara Bulian Kabupaten Batanghari dalam mengembangkan kewirausahaan agrobisnisnya. Untuk itu pimpinan Pondok Pesantren Darul Aufa Sungai Buluh Kecamatan Muara Bulian Kabupaten Batanghari harus mampu menatasi masalah ini, seperti kolam perikanan di tambahkan kelilingnya dengan jaring sehingga jika musim penghujan ikan-ikan yang ada dalam kolam tersebut tidak keluar, dan 
lahan sayur-sayuran di buat sumur untuk mengantisipasi musim kemarau dan atau cara lainnya. Karena sektor agrobisnis rentan terhadap perubahan iklim/cuaca karena berpengaruh terhadap pola tanam, waktu tanam, indeks pertanaman, produksi dan kualitas hasil.

Upaya yang dilakukan Pondok Pesantren Darul Aufa Sungai Buluh Kecamatan Muara Bulian Kabupaten Batanghari dalam mengatasi kendala mengembangkan Kewirausahaan Agrobisnis:

1. Melakukan Study Banding

Persiapan yang kami dilakukan sebelum melakukan studi banding adalah melakukan tinjauan dan evaluasi internal, mengenai mana saja yang akan dikembangkan dan dinaikan progresnya. Setelah itu dibuat draft list secara terstuktur sesuai dengan jadwal yang ditentukan. Penentuan tempat yang akan menjadi tujuan study banding tidak saya putuskan sendiri, melainkan hasil musyawasah kami dengan mempertimbangkan segala asfeknya. Setelah kami tetapkan baru kami melaksanakan komunikasi dengan pihak yang telah ditetapkan dan kemudian baru menjadwalkan pelaksanaannya.

Melakukan study banding untuk menambah pengalaman, pengetahuan dan wawasan untuk setiap individu, tapi yang terpenting dari hal itu adalah sumber daya manusia yang berkompetensi dan manajemen yang baik dari pimpinan, studi banding hanya merupakan upaya untuk meningkatkan kompetensi. Pelaksanaan study banding yang dirancang oleh pimpinan Pondok Pesantren Darul Aufa Sungai Buluh Kecamatan Muara Bulian Kabupaten Batanghari belum mampu meningkatkan kompetensi sumber daya manusia yang ada pada Pondok Pesantren Darul Aufa Sungai Buluh Kecamatan Muara Bulian Kabupaten Batanghari dan belum mampu meingkatkan hasil kewirausahaan agrobisnis yang di kembangkan pada Pondok Pesantren Darul Aufa Sungai Buluh Kecamatan Muara Bulian Kabupaten Batanghari ini.

2. Memanfaatkan Media Sosial untuk Melakukan Pemasaran

Pemasaran hasil agrobisnis Pondok Pesantren Darul Aufa Sungai Buluh Kecamatan Muara Bulian Kabupaten Batanghari melalui media sosial belum mendapatkan minat dari masyarakat umum, dan menurut hemat penulis hal ini dikarenakan Pondok Pesantren Darul Aufa Sungai Buluh Kecamatan Muara Bulian Kabupaten Batanghari melakukan pemasaran dan penawaran hasil produk agrobisnis di media sosial dengan bentuk bahan mentah yang dengan mudah masyarakat bisa temukan di pasar-pasar tradisional. Seharusnya Pondok Pesantren Darul Aufa Sungai Buluh Kecamatan Muara Bulian Kabupaten Batanghari lebih berinovasi lagi dengan hasil agrobisnisnya Pondok Pesantren Darul Aufa Sungai Buluh Kecamatan Muara Bulian Kabupaten Batanghari bisa melakukan produk yang sudah jadi yang sudah dikemas, sehingga ada daya tarik sendiri bagi masyarakat, seperti keripik, atau jenis lainnya. Dengan hasil agrobisnis yang sudah dikemas ini akan lebih mudah memasarkannya di media sosial dan mempunyai daya tarik dan ciri khas tersendiri bagi Pondok Pesantren Darul Aufa Sungai Buluh Kecamatan Muara Bulian Kabupaten Batanghari

3. Menyesuaikan Agrobisnis dengan Cuaca 
Salah satu persoalan yang sangat penting dalam mengembangkan usaha agrobisnis adalah perubahan cuaca. Untuk mengatasinya telah banyak upaya dengan meningkatkan teknologi pertanian; namun sejauh peningkatan teknologi tersebut masih ada kendala yang tidak mudah diatasi dengan teknologi, yakni masalah cuaca dan iklim. Tanaman masih belum dapat dipisahkan dari faktor cuaca dan iklim. Kegagalan panen masih banyak terjadi karena ketidak cukupan cuaca / iklim yang diperlukan bagi tanaman. Iklim telah tersedia secara alami; namun manusia meskipun dengan ilmu dan teknologinya tidak mampu mengendalikan kecuali dalam skala yang terbatas. Oleh karena itu upaya yang bijaksana dalam meningkatkan keberhasilan usaha produksi agrobisnis yang maksimal adalah menyesuaikan kegiatan usahanya dengan peri laku cuaca dan iklim yang ada.

Sebagaimana yang telah diuraikan sebelumnya, bahwa salah satu kendala Pondok Pesantren Darul Aufa Sungai Buluh Kecamatan Muara Bulian Kabupaten Batanghari dalam mengembangkan kewirausahaan agrobisis yaitu perubahan cuaca/iklim, dan salah satu strategi yang dilakukan oleh pimpinan Pondok Pesantren Darul Aufa Sungai Buluh Kecamatan Muara Bulian Kabupaten Batanghari yaitu dengan menyesuaikan cuaca/iklim degan usaha yang akan di kembangkan. Hal ini sebagaimana hasil wawancara penulis dengan pimpinan Pondok Pesantren Darul Aufa Sungai Buluh Kecamatan Muara Bulian Kabupaten Batanghari yang menjelaskan bahwa salah satu upaya yang kami lakukan dalam mengatasi perubahan cuaca atau iklim yaitu dengan menyesuaikan usaha yang akan kami kembangkan. Selanjutnya pimpinan Pondok Pesantren Darul Aufa Sungai Buluh Kecamatan Muara Bulian Kabupaten Batanghari juga menjelaskan bahwa tanaman yang kami kembangkan pada musim panas antara lain jagung dan ubi kayu, karena tanaman ini mampu bertahan di musim panas dan tanaman lainnya yang mampu bertahan pada musim panas atau musim kemarau. Sedangkan pada musim hujan tanaman yang kami kembangkan yaitu cabe, sayur-sayur sayuran dan lainnya.

Wawancara dengan Faturrahim Suaedi, ustadz atau tenaga pendidik yang juga terlibat dalam pengelolaan agrobisnis Pondok Pesantren Darul Aufa Sungai Buluh Kecamatan Muara Bulian Kabupaten Batanghari menjelaskan bahwa untuk mengatasi perubahan cuaca, kami menyesuaikan usaha yang kami tanam dengan cuaca, minsalnya musim pengujan kami menanamkan cabe, sayur-sayuran dan tanaman sejenisnya, sedangkan pada musim panas kami menenam jagung, umbi-umbian dan tanaman sejenisnya.

Tanaman selain memerlukan tanah tertentu dan kecukupan zat hara, juga memerlukan air dan radiasi matahari yang cukup dalam waktu bersamaan. Dari sifat tersebut dapat dikemukakan bahwa paling tidak ada tiga hal pokok yang harus diperhatikan dalam produksi pertanian tanaman, yaitu Kebutuhan dan tanggap tanaman kepada cuaca dan iklim, tanah, dan air, Karateristik lokasi dari unsur tanah (fisik maupun kimiawi).

Karakteristik lokasi dari unsur cuaca dan iklim. Kegiatan pertanian, kehidupan tanaman, berlangsung secara terus-menerus fase demi fase, dan setiap fase memerlukan kondisi cuaca tertentu. Demikian pula cuaca terus- 
menerus berlangsung dan juga selalu berubah. Namun demikian perubahan tersebut tidak selalu sejalan dengan yang diperkukan bagi tanaman dalam fase itu.

Dengan demikian memonitor, termasuk menganalisis dan memprediksi cuaca / iklim perlu dilakukan agar dapat dilakukan penilaian dan upaya penyesuaian dengan adanya cuaca yang terjadi atau yang akan terjadi. Dalam setiap fase kehidupan tanaman terpengaruh oleh kondisi lingkungan termasuk tanah, air, cuaca. Oleh karena itu yang perlu diketahui adalah sejauh mana kondisi lingkungan tersebut mempengaruhi atau akan mempengaruhi kehidupan tanaman. Adanya fenomena ekstrem misalnya banjir dapat secara langsung merusak tanaman. Upaya pecegahan atau pelindungan perlu dilakukan. Kegiatan pertanian adalah upaya yang berkaitan dengan pembudi dayaan tanaman. Kegiatan pertanian sangat beragam, demikian pula nilai cuaca dan iklim yang diperlukan.

Pada dasarnya cuaca/iklim dimanfaatkan untuk membuat perencanaan, yakni perencanaan stratejik dan perencanaan operasional, serta pengendalian pelaksanaan kegiatan pertanian. Perencanaan stratejik meliputi perencanaan tata guna lahan, perencanaan pola tanam. Perencanaan operasional meliputi perencanaan penyiapan tanah, pembibitan, penanaman, pemeliharaan. Pelaksanaan kegiatan meliputi pengolahan tanah, pembibitan, penanaman, pemeliharaan, panen, pasca panen, transportasi. Cuaca selalu berubah dan berbeda setiap waktu dan di setiap tempat. Perubahan tersebut ada yang tidak beraturan dan ada yang beraturan. Yang tidak beraturan umumnya berlangsung dalam waktu pendek yang ditimbulkan oleh prosesproses sementara dalam atmosfer. Sedangkan yang beraturan berkaitan dengan perubahan-perubahan alam dalam skala besar, misalnya yang utama karena, perputaran bumi pada porosnya, peredaran bumi mengelilingi matahari, perubahan fisik matahari. Dengan kondisi cuaca yang demikian, langkah yang diambil Pondok Pesantren Darul Aufa Sungai Buluh Kecamatan Muara Bulian Kabupaten Batanghari dalam mengatasi perubahan cuaca ini menurut hemat penulis sudah tepat dengan menyesuaikan karakteristik tanaman dengan cuaca atau iklim yang sedang berlangsung.

\section{KESIMPULAN}

Berdasarkan dari hasil penelitian dan pembahasan sebagaimana telah penulis uraikan pada bab sebelumnya, maka dalam penelitian yang berjudul Manajemen Pondok Pesantren dalam Mengembangkan Kewirausahan Agrobisnis di Pondok Pesantren Darul Aufa Sungai Buluh Kecamatan Muara Bulian Kabupaten Batanghari dapat penulis simpulkan sebagai berikut:

1. Manajemen yang dilakukan pimpinan Pondok Pesantren Darul Aufa Sungai Buluh Kecamatan Muara Bulian Kabupaten Batanghari dalam mengembangkan kewirausahaan agrobisnis dalam sistem pondok pesantren yaitu dengan mengfungsikan fungsi-fungsi manajemen, yaitu dengan melakukan perencanaan, pengorganisasian, penggerakan dan pengawasan. Perencanaan yang dilakukan pimpinan Pondok Pesantren Darul Aufa Sungai Buluh Kecamatan Muara Bulian 
Kabupaten Batanghari dalam mengembangkan kewirausahaan agrobisnis tidak dilakukan secara sistematis, perencanaan dilakukan melalui hasil musyawarah dengan para ustadz dan hasil tersebut tidak dituangkan dalam bentuk dokumen perencanaan. Pengorganisasian yang dilakukan pimpinan Pondok Pesantren Darul Aufa Sungai Buluh Kecamatan Muara Bulian Kabupaten Batanghari dalam mengembangkan kewirausahaan agrobisnis yaitu dengan mengfungsikan ustadz dan para santri, penggerakan juga dilakukan dengan menggerakkan para ustadz dan para santri dalam mengelola dan mengembangkan kewirausahaan agrobisnis Pondok Pesantren Darul Aufa Sungai Buluh Kecamatan Muara Bulian Kabupaten Batanghari. pengawasan yang dilakukan pimpinan Pondok Pesantren Darul Aufa Sungai Buluh Kecamatan Muara Bulian Kabupaten Batanghari tidak dilakukan secara sistematis dan berkesinambungan.

2. Adapun Kendala Pondok Pesantren dalam Mengembangkan Kewirausahaan Berbasis Agrobisnis di Pondok Pesantren Darul Aufa Sungai Buluh Kecamatan Muara Bulian dalam mengembangkan kewirausahaan agrobisnis yaitu tidak tersedianya sumber daya manusia yang berkompetensi dan berkualifikasi dalam bidang agrobisnis, sehingga terjadi kesulitan untuk mengembangkan kegiatan agribisnis ini, kendala berikutnya kesulitan dalam melakukan pemasaran hasil agrobisnis karena kurangnya Kerjasama dengan pihak luar untuk dijadikan peasaran hasil agribisnis ini. Dan terakhir perubahan cuaca yang sering terjadi perubahan yang menyebabkan gagal panen dari kegiatan agribisnis ini yang juga merupakan kendala bagi pimpinan Pondok Pesantren Darul Aufa Sungai Buluh Kecamatan Muara Bulian Kabupaten Batanghari dalam mengembangkan kewirausahaan agrobisnis

3. Upaya yang dilakukan Pondok Pesantren dalam Mengembangkan Kewirausahaan Berbasis Agrobisnis di Pondok Pesantren Darul Aufa Sungai Buluh Kecamatan Muara Bulian dalam mengatasi kendala dalam mengembangkan kewirausahaan agrobisnis pada Pondok Pesantren Darul Aufa Sungai Buluh Kecamatan Muara Bulian Kabupaten Batanghari yaitu dengan melakukan studi banding kebeberapa pondok pesantren yang juga mengembangkan kewirausahaan dalam sistem pondok pesantren. Studi banding ini dilakukan untuk mengamati kegiatan yanag dilakukan oleh pondok pesantren lain dlam mengelola agrobisnisnya. Upaya lain yang dilakukan adalah dengan Memanfaatkan media sosial dalam melakukan pemasaran hasil usaha agrobisnis ataupun bekerja sama dengan pihak lain untuk mpemasarannya dan selanjutnya pondok pesantren harus menyesuaikan antara tanamanan agrobisnis dengan perubahan cuaaca atau iklim pada saat tanam.

\section{REFERENSI}

Ahmad Muthohar. (2007). Idologi Pendidikan Pesantren. Jakarta: Pustaka.

Anik Farida, dkk. (2007) Modernisasi Pesantren. Jakarta: Balai Penelitian dan Pengembangan Agama. 
George R. Terry. (2009). Priinsip-prinsip Manajemen, Jakarta: Bumi Aksara.

George R. Terry, Leslie W. Rue, (2011). Dasar-dasar Manajejmen, Jakarta: Bumi Aksara.

Husaini Usman. (2010). Manajemen, Teori, Praktik, dan Riset Pendidikan, Jakarta: PT. Bumi Aksara.

Lexy J. Moleong. (2010). Metodologi Penelitian Kualitatif. Bandung: Remaja Rosda Karya.

Mukhtar. (2013). Metode Praktis Penelitian Deskriptif Kualitatif. Jakarta: Referensia/GP. Press Group.

Nana Syaodih Sukmadinata. (2011). Metode Penelitian Pendidikan. Bandung: PT.Remaja Rosdakarya Offset.

Ngalim Purwanto. (2009). Administrasi dan Supervisi Pendidikan. Bandung: PT. Remaja Rosdakarya.

Noor Ahmady, Pesantren Dan Kewirausahaan (Peran Pesantren Sidogiri Pasuruan Dalam Mencetak Wirausaha Muda Mandiri). Executive Summary Penelitian di Lemlit UIN Sunan Ampel Surabaya.

Robert K. Yin. (2011). Qualitative Research from Start to Finish. New York London: The Guilford Press.

Syaiful Sagala. (2008). Administrasi Pendidikan kontemporer, Bandung : Alfa Beta.

Team Peneliti. (2007) Sejarah Pesantren di Indonesia. Jakarta. 